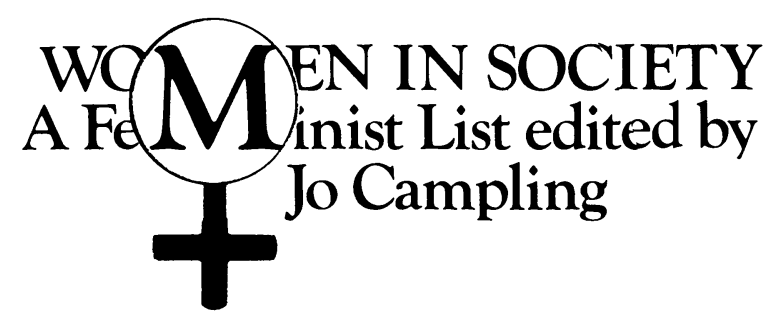

editorial advisory group

Maria Brenton, University College, Cardiff; Phillida Bunckle, Victoria University, Wellington, New Zealand; Miriam David, Polytechnic of the South Bank; Leonore Davidoff, University of Essex; Janet Finch, University of Lancaster; Jalna Hanmer, University of Bradford; Beverley Kingston, University of New South Wales, Australia; Hilary Land, University of Bristol; Diana Leonard, University of London Institute of Education; Susan Lonsdale, Polytechnic of the South Bank; Jean O'Barr, Duke University, North Carolina, USA; Arlene Tigar McLaren, Simon Fraser University, British Columbia, Canada; Jill Roe, Macquarie University, Australia; Hilary Rose, University of Bradford; Susan Sellers, Centre D'Etudes Feminines, Université de Paris; Pat Thane, Goldsmiths' College, University of London; Jane Thompson, University of Southampton; Clare Ungerson, University of Kent at Canterbury; Judy Walkowitz, Rutgers University, New Jersey, USA.

The 1970s and 1980s have seen an explosion of publishing by, about and for women. This new list is designed to make a particular contribution to this process by commissioning and publishing books which consolidate and advance feminist research and debate in key areas in a form suitable for students, academics and researchers but also accessible to a broader general readership.

As far as possible books will adopt an international perspective incorporating comparative material from a range of countries where this is illuminating. Above all they will be interdisciplinary, aiming to put women's studies and feminist discussion firmly on the agenda in subject-areas as disparate as law, physical education, art and social policy. 


\section{Published}

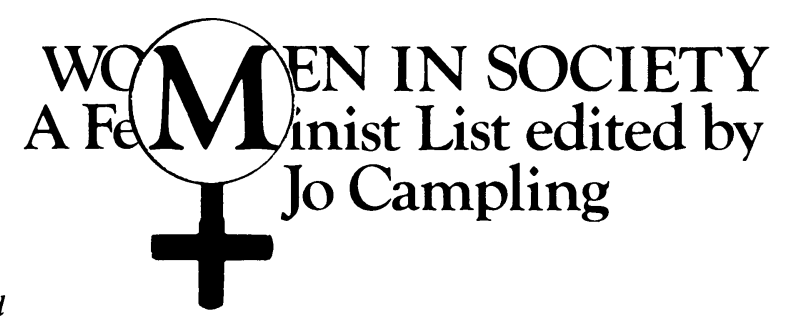

Sheila Allen and Carol Wolkowitz Homeworking: myths and realities

Jenny Beale Women in Ireland: voices of change

Gillian Dalley Ideologies of Caring: rethinking community and collectivism

Leonore Davidoff and Belinda Westover (editors) Our Work, Our Lives, Our Words: women's history and women's work

Diana Gittins The Family in Question: changing households and familiar ideologies

Frances Heidensohn Women and Crime

Muthoni Likimani (with an introductory essay by Jean O'Barr) Passbook Number F.47927: women and Mau Mau in Kenya

Sharon Macdonald, Pat Holden and Shirley Ardener (editors) Images of

Women in Peace and War: cross-cultural and historical perspectives

Vicky Randall Women and Politics: an international perspective (2nd edition)

Rosemary Ridd and Helen Callaway (editors) Caught Up in Conflict: women's responses to political strife

Clare Ungerson (editor) Women and Social Policy: a reader

\section{Forthcoming}

Eileen Aird and Judy Lown Education for Autonomy: processes of change in women's education

Jennifer Breen Women and Fiction

Maria Brenton Women and Old Age

Sheila Button Women and Local Politics

Ruth Carter and Gill Kirkup Women in Engineering

Angela Coyle and Jane Skinner Women and Work: positive action for equal opportunities

Audrey Droisen and Emily Driver (editors) Child Sexual Abuse: a feminist perspective

Lesley Ferris Acting Women: images of women in the theatre

Tuula Gordon Feminist Mothers

Frances Gray Women and Laughter

Eileen Green, Diana Woodward and Sandra Hebron Women and Leisure

Jennifer Hargreaves Women and Sport

Annie Hudson Troublesome Girls: adolescence, femininity and the state

Ursula King Women and Spirituality

Jo Little, Linda Peake and Pat Richardson (editors) Women in Cities: gender and the urban environment

Susan Lonsdale Women and Disability

Jan Pahl Marriage and Money

Shelley Pennington and Belinda Westover A Hidden Workforce: women homeworkers in Britain

Lesley Rimmer Women's Family Lives

Susan Sellers Language and Sexual Difference: feminist writing in France

Patricia Spallone Beyond Conception: the new politics of reproduction

Taking Liberties Collective Learning the Hard Way: women's oppression in men's education

Jane Thompson Introducing Women's Studies

Deborah Valenze The Other Victorian Woman

Janet Wolff The Art of Women

Ann Woodhouse Sex, Gender and Transvestism 


\title{
Images of Women in Peace and War
}

Cross-Cultural and Historical Perspectives

\author{
Edited by \\ Sharon Macdonald, \\ Pat Holden \\ and
}

Shirley Ardener

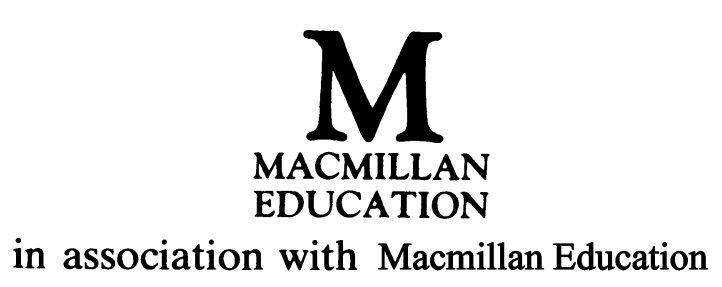


Selection and editorial matter (C) Sharon Macdonald, Pat Holden and Shirley Ardener 1987

Individual chapters (C) Sharon Macdonald, Ilse Kirk, Sharon Macdonald, Penny Dransart, Tabitha Kanogo, Elaine Unterhalter, Rosemary McKechnie, Jessica Mayer, Margaret Brooks, Lynne Jones, Ruth Roach Pierson 1987

All rights reserved. No reproduction, copy or transmission of this publication may be made without written permission.

No paragraph of this publication may be reproduced, copied or transmitted save with written permission or in accordance with the provisions of the Copyright Act 1956 (as amended), or under the terms of any licence permitting limited copying issued by the Copyright Licensing Agency, 33-4 Alfred Place, London WC1E 7DP.

Any person who does any unauthorised act in relation to this publication may be liable to criminal prosecution and civil claims for damages.

First published 1987

Published by

MACMILLAN EDUCATION LTD

Houndmills, Basingstoke, Hampshire RG21 2XS

and London

Companies and representatives

throughout the world

Photoset in Times by CAS Typesetters, Southampton

British Library Cataloguing in Publication Data

Images of women in peace and war: cross-

cultural and historical perspectives. -

(Women in society).

1. Women and war

I. Macdonald, Sharon II. Holden, Pat

III. Ardener, Shirley IV. Series

$303.6 \quad \mathrm{U} 21.75$

ISBN 978-0-333-42895-5 ISBN 978-1-349-18894-9 (eBook)

DOI 10.1007/978-1-349-18894-9

\section{Series Standing Order}

If you would like to receive future titles in this series as they are published, you can make use of our standing order facility. To place a standing order please contact your bookseller or, in case of difficulty, write to us at the address below with your name and address and the name of the series. Please state with which title you wish to begin your standing order. (If you live outside the United Kingdom we may not have the rights for your area, in which case we will forward your order to the publisher concerned.)

Customer Services Department, Macmillan Distribution Ltd, Houndmills, Basingstoke, Hampshire, RG21 2XS, England. 


\title{
BOOKS SPONSORED BY THE OXFORD UNIVERSITY WOMEN'S STUDIES COMMITTEE
}

\author{
Published by Macmillan Education
}

Caught Up in Conflict: women's responses to political strife edited by Rosemary Ridd and Helen Callaway, 1986.

Images of Women in Peace and War: cross-cultural and historical perspectives

edited by Sharon Macdonald, Pat Holden and Shirley Ardener, 1987.

Published by Croom Helm Ltd, Provident House, Burrell Row, Beckenham, Kent BR3 1AT:

Defining Females: the nature of women in society edited by Shirley Ardener, 1978.

Fit Work for Women edited by Sandra Burman, 1979.

Women Writing and Writing About Women edited by Mary Jacobus, 1979.

Women and Space: ground rules and social maps edited by Shirley Ardener, 1981.

Controlling Women: the normal and the deviant edited by Bridget Hutter and Gillian Williams, 1981.

Women's Religious Experience edited by Pat Holden, 1983.

Women and Property, Women as Property edited by Renée Hirschon, 1984.

Women and Work in Pre-industrial Britain, 1300-1700 edited by Lorna Duffin and Lindsey Charles, 1985. 


\section{Contents}

List of Plates xii

Acknowledgements xiii

Notes on the Contributors xv

Preface by Shirley Ardener and Pat Holden xvii

1 Drawing the Lines - Gender, Peace and War: An Introduction

Sharon Macdonald

The power of imagery 2

Female fighters and male myths 6

Ideal or unnatural? Images of ancient warrior women 6

Social struggle and the imposition of imagery 8

Social order and the female soldier $\quad 10$

Maternity and militaries 13

Women where men wage war $\quad 15$

Everyday lives and sexual identities $\quad 17$

Order, rebellion and body symbolism 19

Transforming gender, peace and war 20

Images and actions $\quad 22$

2 Images of Amazons: Marriage and Matriarchy 27

Ilse Kirk

Amazons in ancient Greece $\quad 27$

Marriage not war $\quad 29$

Bachofen and matriarchy $\quad 32$

Contemporary views of Amazons 33

Conclusion $\quad 36$ 
3 Boadicea: Warrior, Mother and Myth 40

Sharon Macdonald

An historical puzzle $\quad 40$

Sexual anomaly $\quad 41$

Boadicea's story 41

A Celtic anomaly? 42

Sexual symbolism in the classical texts 43

Tacitus $\quad 43$

Dio's inventions and inversions $\quad 44$

Honourable matron and virgin queen $\quad 46$

Upholding the honour of British ladies 46

Boadicea and Elizabeth I 48

Unnatural woman $\quad 49$

National and feminist symbol $\quad 51$

The two 'Victorias' 52

As representative of women $\quad 54$

Conclusion $\quad 55$

4 Women and Ritual Conflict in Inka Society 62

Penny Dransart

The Spanish conquest $\quad 62$

Inka women on the battle-field 64

The nature of war in Inka society 65

The complementary roles of women $\quad 66$

Women, fertility and war $\quad 68$

$\begin{array}{ll}\text { Female deities } & 70\end{array}$

$\begin{array}{ll}\text { Ritual conflict } & 71\end{array}$

Historical misrepresentation $\quad 73$

$\begin{array}{ll}\text { Conclusion } & 74\end{array}$

5 Kikuyu Women and the Politics of Protest: Mau Mau 78

Tabitha Kanogo

Kikuyu women before Mau Mau $\quad 79$

The colonial background $\quad 79$

Women's traditional roles $\quad 80$

Women's protest $\quad 80$

The Harry Thuku riot (1922) 80

The revolts of 1947, 1948 and $1951 \quad 82$

Mau Mau women: The oath $\quad 85$

Women of the forest $\quad 87$ 
Roles and stereotypes $\quad 87$

Women warriors $\quad 88$

Political roles $\quad 89$

Mau Mau women on the domestic front $\quad 89$

Provision of food $\quad 90$

Children $\quad 91$

New roles for women $\quad 91$

Domestic strife and social reorganisation 91

An evaluation of women's involvement in

Mau Mau political militancy: the case of

Wanjiru Nyamarutu 93

Women and killing $\quad 94$

Continuing the struggle $\quad 94$

The impact of Mau Mau on Kenyan women today 96

6 Women Soldiers and White Unity in Apartheid South Africa

Elaine Unterhalter

The defence force and South African society 101

The early recruitment of women 103

The expansion of women's deployment 106

The socio-economic background of women recruits

Women's roles in the military 113

Military training for women $\quad 115$

$\begin{array}{ll}\text { Soldiers and 'femininity' } & 117\end{array}$

White South Africa's view of women soldiers 118

$\begin{array}{ll}\text { Conclusion } & 120\end{array}$

7 Living With Images of a Fighting Elite: Women and the Foreign Legion

122

Rosemary McKechnie

Historical background: the formation of a fighting elite

Views of Legion women

La grande famille: the basis of the mystique 126

Keeping women in their place: rules and

regulations

Marriage 128

Christmas: virgins and godmothers 130 
Women and wives

Living with the Legion: la cité des cocus

Reality and imagery: women's views

8 Women and the Pacification of Men in New Guinea

Jessica Mayer

Ommura society before and during pacification

Men as protectors

Fighting and drudging

Women's responsibilities and rights

Female dissent

Men's work and the ideology of masculine strength

Warfare

Protection and healing

Sickness and weakness

Women's world-views

Alternative models

Pacification: impotence

Assochia: potency regained

The assochia ceremony

The ideology of diagnosis

Conclusion

9 Passive in War? Women Internees in the Far East

1942-5

Margaret Brooks

The internment camps

Life in the camps

Civilisation inside the fence

Protection through symbolism

173

Survival and death

Victories

10 Perceptions of 'Peace Women' at Greenham Common 1981-5

Lynne Jones

Media images

Public opinion

Self-perception

'Women only' 
Political motivation $\quad 190$

Creative structure $\quad 191$

Political symbolism 194

Communication of ideas 194

Symbolic action $\quad 195$

Symbolic connections and actions $\quad 200$

Power of symbolism 200

Non-violence 201

11 'Did Your Mother Wear Army Boots?' : Feminist

Theory and Women's Relation to War, Peace and Revolution

205

Ruth Roach Pierson

Early feminist views on women and war 205

The revolutionary tradition $\quad 207$

Separate spheres and the ideology of motherhood 211

The impact of the First World War 213

Virginia Woolf's Three Guineas (1938) 217

Contemporary Feminisms 221

Conclusion 225

$\left.\begin{array}{l}\text { Name Index } \\ \text { Subject Index }\end{array}\right\} \quad$ by Isobel Bowler 228 


\section{List of Plates}

1 Boadicea as champion of women's suffrage 56

2 Inka vase 69

3 Women in the South African Defence Force (SADF)

4 Women at Greenham Common holding up mirrors for the police to see themselves, 12 December 1983

5 Illustration by Catriona Howse from leaflet produced for the Dragon Action, Greenham Common, 24 June 1983 


\section{Acknowledgements}

The editors and publishers acknowledge with thanks permission from the following to reproduce the cover photograph and illustrations in the text:

Mary Evans Picture Library for the cover photograph; Mary Evans/ Fawcett Library for the illustration of Boadicea in Plate 1; The Trustees of the National Museum of Scotland for the illustration of an Inka vase in Plate 2; IDAF for the illustration of women SADF members in Plate 3; Paula Allen for the illustration of women at Greenham Common in Plate 4; Catriona Howse for the illustration from the Dragon Action leaflet in Plate 5.

The editor and publishers also acknowledge with thanks permission from the following to reproduce extracts in the text: Department of Sound Records, Imperial War Museum; and CND for quotes from an unpublished independent report of research which it commissioned. 


\section{Notes on the contributors}

Shirley Ardener, of the Centre for Cross-Cultural Research on Women, Queen Elizabeth House, University of Oxford, is the author of numerous publications and editor of Perceiving Women, 1975, Defining Females, 1978, Women and Space, 1981, The Incorporated Wife (with Hilary Callan), 1984 and Visibility and Power, Essay on Women in Society and Development (with Leela Dube and Eleanor Leacock) 1987. She is a social anthropologist who has carried out extensive fieldwork in Cameroon.

Margaret Brooks is Keeper of Sound Records at the Imperial War Museum, London.

Penny Dransart is undertaking research at the Ethnology Department, University of Oxford. She has done fieldwork in Peru, Chile and Bolivia.

Pat Holden is a Research Associate at the Centre for Cross-Cultural Research on Women, Queen Elizabeth House, Oxford. She is the editor of Women's Religious Experience, 1983 and of Anthropological Approaches to Nursing (forthcoming). She has lived and worked in Uganda, Malawi, Nigeria and Egypt.

Lynne Jones read human sciences at Oxford. A medical doctor who has lived at Greenham Common Peace Camp for extended periods of time, she is a regular contributor to the New Statesman and editor of Keeping the Peace, 1983.

Tabitha Kanogo lectures in the department of History at Kenyatta University College, Nairobi. She was recently Rhodes Fellow, 
Somerville College, University of Oxford. She is author of Squatters and the Roots of Mau Mau, 1905-1963 (1987).

Ilse Kirk was formerly Research Fellow at the Institute of Ethnology and Anthropology, University of Copenhagen, with a project called 'Women in the Stone and Bronze Ages', and at the Centre for Cross-Cultural Research on Women at Oxford.

Sharon Macdonald, who read human sciences at St Catherine's College, Oxford, is carrying out research in social anthropology at the Institute of Social Anthropology, Oxford. She was awarded a Sir John Rhŷs Studentship for Celtic Studies in 1986. She has recently carried out fieldwork in the Isle of Skye.

Jessica Mayer is doing research at the University of Sussex and teaching part-time at Goldsmith's College, London. She has done fieldwork in New Guinea.

Rosemary McKechnie is undertaking research in social anthropology at the Institute of Social Anthropology, Oxford. She has recently returned from fieldwork in Corsica.

Ruth Roach Pierson is Associate Professor at the Ontario Institute for Studies in Education. She is the author of They're Still Women After All: The Second World War and Canadian Womanhood, 1986, and the editor of Women and Peace, 1987.

Elaine Unterhalter is Senior Research officer in the Department of Sociology, University of Essex. She is a member of the Women in South African History Study Group. 


\section{Preface}

This volume is the latest in the series sponsored by the Oxford University Women's Studies Committee; previous titles are listed in the front of this book. The editors have selected studies which consider women's direct involvement as active participants in both peace movements and in wars, and also studies which discuss the more diffuse, pervasive, realm of ideas which conjures up images identifying women sometimes as warriors, sometimes as peacemakers. We were aware, of course, that the distinction is not absolute since the reification of women - whereby they do duty as manipulable symbols - bears crucially upon the world of practice.

The definition of 'war' has always been problematic - as declared war shades through guerrilla-type resistance movements into urban violence, for example. Different interpretations of a conflict and its context may co-exist, though not necessarily in harmony. For example, there may be differing views even as to whether a state of peace or war exists. A particularly acute awareness of definitional problems has arisen in recent years with the existence of nuclear weapons; these are claimed by one side as evidence for the keeping of the peace in Europe and by the other as evidence of a permanent state of war. The terminology 'cold' applied to war is itself suggestive. The problem of apparent identities masking difference is illustrated by women's peace-movements which have been in existence for a long time but today are a response to a new set of ideas, circumstances and techniques, firmly located in feminism. The term 'Amazon', as Isle Kirk shows (Chapter 2), has been applied in widely different contexts; these range from the original ancient European texts to the female militia of nineteenth-century Dahomey (see the cover). Further, peace and war are indefinable one without the other and the varied nature of women's involvements in both is explored in this book. 
Just as ideas of war and peace are mutually defined, so concepts of men and women are mutually contrasted and reflected. The wide variety of historical and cross-cultural situations addressed here show that women's roles in both war and peace-movements are very much determined by broader perceptions of gender and notions of appropriate female roles held by the societies to which they belong.

Stereotypes of maleness - particularly those evoked in time of war - throw into exaggerated contrast imagery and symbolism associated with women. Compatabilities and inconsistencies become especially critical when women are incorporated into active military service. Further, women in war situations often form organisations that structurally replicate those of men, but which express very different sets of values and self-perceptions. On the other hand some contemporary peace-movements in Britain have attempted to dissolve certain common institutional structures, and in doing so pose a challenge to the much wider arena of perceptions of gender-difference, thus evoking both praise and criticism.

As social anthropologists, the editors ensured that the book would not be restricted to contemporary British material, but would range widely over time and space: that it would be cross-cultural. Of course, the limitations of book length posed problems for such ambition. A selection of available material has had to be made; a certain arbitrariness has been inevitable. But we make no apologies for adopting this course even though darting across contours of space and time may open us to charges of lack of comprehensiveness and consistency. The avoidance of complete ethnocentricity makes this worthwhile.

The studies selected were drawn from different sources. Three derive from a seminar series convened by the editors for the Oxford University Women's Studies Committee in 1983: those by Jessica Mayer, Lynne Jones and Margaret Brooks. The papers by Sharon Macdonald, Rosemary McKecknie, Tabitha Kanogo and Penny Dransart were first given at the Oxford Women's Social Anthropology Seminar. ${ }^{1}$ The papers by Ilse Kirk, Ruth Roach Pierson ${ }^{2}$ and Elaine Unterhalter were written especially for this volume.

Discussions during the seminars referred to, and informally afterwards, have played an important part in forming some of the ideas expressed in this book, and we are grateful to those who participated. Timothy Ashplant helped plan the Committee's seminar, and Alison Smith, Helen King and Jill Cook all offered 
useful editorial advice: we thank them. While editing this book has been a co-operative excercise, we wish to acknowledge the special role of Sharon Macdonald who not only wrote the Introduction, but shouldered a disproportionate part of the editorial function.

SHIRLEY ARDENER, PAT HOLDEN

Queen Elizabeth House, Oxford

\section{Notes}

1. Attention is drawn to a number of papers given in the women's Studies Committee's programme and at the Oxford Women's Social Anthropology Seminar which could not be included in this book, so that readers may consult those in print elsewhere and may contact the authors of others. Thus at the Committee's seminar, Anne Armstrong (Anne Mayo) formerly of the British Army, currently editor of Neighbours (the journal of the British Army wives' club), gave a paper on 'Women in the British and US Armed Forces' which included some comparative material from other armies. Lindiwe Guma and Elaine Unterhalter spoke on 'Women in the National Liberation Struggle of the ANC'. Anne Summers gave a paper which now forms part of her book Angels and Citizens: British Women as Military Nurses 1854-1914 (Routledge \& Kegan Paul). Marina Warner's talk on 'The Language of War in the Allegories of Virtue: from Nike to Margaret Thatcher' is embodied in her Monuments and Maidens. The Allegory of the Female Form (Weidenfeld \& Nicholson, 1985), Mandy Merck's contribution on Amazons was based on her paper in Tearing the Veil (ed. Susan Lipshitz, Tavistock, 1978).

Papers given at the social anthropology seminar of special relevance to the themes of this book include 'Women Warriors in Traditional Ethiopia' by Tsehai Berhane Selassie, a version of which has appeared in the Journal of the Anthropological Society of Oxford (JASO XII, 1, 1981) as "Centre" and "Periphery" in History; The Case of Warriors and Women in traditional Ethiopia'. Sabine Willis spoke on 'Anzac Day and Women' (see 'Rape - Our Window of Vulnerability' in Social Alternatives I, 3, 1984). Ilse Kirk gave a paper on 'The Ibo Women's War' which is soon to be published in Denmark, as well as a paper on the so-called 'Amazons of Dahomey' in West Africa. A short version of Audrey Wipper's paper on 'Riot and Rebellion among African Women: three examples of women's political clout', can be found in Perspectives on Power (ed. Jean O'Barr, Durham USA, 1982). Jean O'Barr, of Duke University, in her seminar paper on Kenyan writers, prefigured her Introductory Essay to Passbook Number F.47927: Women and Mau 


\section{xx Preface}

Mau in Kenya by Muthoni Likimani, published by Macmillan Education in this series (1985). See also Mona Macmillan's Study 'Camp Followers: A Note on Wives of The Armed Services' in The Incorporated Wife, eds. H. Callan and S. Ardener (Croom Helm, 1984).

2. An earlier version of the paper by Ruth Roach Pierson was delivered at the Conference on 'Gender and War: Historical, Political and CrossCultural Perspectives', sponsored by the Program in Women's Studies and the Shelby Cullom Davis Center for Historical Studies, Princeton University, 17 March 1984. 